From the Department of Oral- and Maxillofacial Surgery, Semmelweis University of Medicine, Budapest, Hungary

\section{Invited Commentary to: „Regionale Diagnostik und Therapie bei Plattenepithelkarzinomen der Mundhöhle und des Oropharynx"}

\section{G. Szabó, J. Barabás, and Z. Németh}

The article by Millesi et al. (3) deals with an important and topical question. The mortality rate due to cancers in the oral cavity is tending to increase worldwide. During the past 30 years, the mortality rate due to tumours of all types in Hungary has risen by a factor of 1.5 times, whereas that due to cancers in the oral cavity has risen by a factor of 5 times (4).

In Europe, Hungary has the highest mortality rate due to cancers in the oral cavity for both men and women (2). In contrast, Austria is in 17 th place for men, and 24th place for women. There is a difference of some 2.5 -fold between the 2 countries: a death rate of 16.5 or 6.2 per 100,000 for men, and of 2.1 or 0.9 per 100,000 women. Among the known etiological factors, smoking and alcohol consumption play the main roles. The study by Dietz (1) revealed that, if the relative risk factor for cancers in the oral cavity among non-smokers is taken as 1 , then that for someone smoking 2 packets of cigarettes a day is 15 . Similarly, the relative risk factor is increased 13 -fold by the daily consumption of $45 \mathrm{~g}$ of alcohol. The combination of smoking and alcohol consumption elevates the risk proportionally. These findings were confirmed by the results of screening examinations in alcohol-withdrawal units and among the homeless. The screening of 300 individuals at risk demonstrated untreated malignant processes in the oral cavity or its vicinity in $2.66 \%$ of the cases (!) (4).

The increasing occurrence and mortality of cancers in the oral cavity can be influenced only slightly with the modern diagnostic and therapeutic tools. Help is primarily to be expected from social prevention, as occurred in the United States and France.

Although the situation relating to the mortality of cancers in the oral cavity is substantially better in Austria than in Hungary, similar problems must naturally be overcome as concerns the diagnostic and therapeutic principles.

We agree completely with the authors (3) as regards the detailed diagnostics, and also the fact that, from the aspect of the routine, apart from the classical clinical examinations, the greatest help is perhaps provided by ultrasonographic diagnostic, CT and MR yield more information only in certain cases.

As far as the therapeutic principles are concerned, there are a number of situations where the attitudes may differ. However, there is a uniform tendency toward functional surgery, which is also reflected in the work of Millesi et al. (3).

When the oncologic aspects are considered, radical neck dissection should not be insisted on at all costs. The distribution of suprahyoid, functional and radical dissection corresponds fully to the described step-by-step conception. Our own results are support the fact that, in the long term, functional dissection does not give poorer results than those of radical dissection (5).

A striking feature in the results of Millesi et al. (3) is the $10 \%$ perioperative mortality. Apart from appreciating this honest revelation of the facts, we consider it unacceptable that every 10 th patient should die from postoperative complications. The question arises of whether this high proportion might possibly be connected with the preoperative treatment. The combination of intensive cytostatic and irradiation treatment may weaken the resistance necessary to tolerate the radical operation. It should also

Corresponding address: G. Szabó, M.D., Department of Oral and Maxillofacial Surgery, Semmelweis University of Medicine, Mária u. 52, H-1085 Budapest, Hungary.

Fax: $++36 / 1 / 266-0456$

E-mail: szabo@szajseb.sote.hu be considered whether such preoperative treatment must unconditionally be followed by immediate microsurgical reconstruction in all cases, as this increases the duration of the otherwise not short surgery, with a resultant greater stress on the patient. It is not a matter of definitely omitting the microsurgical reconstruction, of course, but merely of assessing whether the given patient is able to tolerate the intervention. It is necessary to discuss these situations, for a perioperative mortality rate of $10 \%$ may call into question the entire therapeutic conception.

On the other hand we agree in full that the microsurgical reconstruction will lead to a major improvement in the postoperative quality of life.

\section{References}

(1) Dietz A: Beitrag zur Ermittlung von Risikofaktoren für die Entstehung von Plattenepithelkarzinomen des oberen Aerodigestivtraktes - eine Fall-Kontrollstudie. Heidelberg, Med Diss, 1991.

(2) Levi F, La Vecchia C. Lucchini F, Negri E: Cancer mortality in Europe, 1990-92 Eur J Cancer Prev 1995;4:389-417.

(3) Millesi W, Steiner E, Dobrowsky W, Glaser C, Wild K, Öckher M: Regionale Diagnostik und Therapie bei Plattenepithelkarzinomen der Mundhöhle und des Oropharynx. Acta Chir Austriaca 1998;30:299-305.

(4) Szabó G. Klenk G, Veér A: Correlation of the combination of alcoholism and (4) Szabo G. Klenk G, Veér A: Correlation of the combination of alcoholism and smoking with the occurence of cancer in the oral cavity (a screening study
endangered population). Orvosi Hetilap 1997;138:3297-3299 (in Hungarian). (5) G. Szabó G, Kovács Á, Barabás J, Suba S: Long-term studies concerning intraarterial cytostatic treatment of tumours of the head and neck. Reg Cancer Treat 1989 2: $20-23$.

\section{Schlußwort der Autoren}

Thema der vorliegenden Arbeit war die Evaluierung der regionären Therapie bei Patienten mit Plattenepithelkarzinomen der Schleimhaut der Mundhöhle und des Oropharynx. Neben einer kombinierten Behandlung, bestehend aus einer präoperativen Radiochemotherapie, kam operativ neben einer lokal-radikalen Resektion ein abgestuftes Konzept der Dissektion der regionären Halslymphknoten mit Erhaltung der Äste der A. carotis externa für einen mikrochirurgischen Gefäßanschluß zur primären Wiederherstellung zur Anwendung. Dies wurde durch die Fortschritte der präoperativen Diagnostik ermöglicht. Mit einer organ- und funktionserhaltenden bzw. wiederherstellenden Therapie konnten präliminar gute Ergebnisse hinsichtlich Rezidivraten, ohne Erhöhung im regionären Bereich, erzielt werden.

Hinsichtlich der 8 an perioperativen Komplikationen verstorbenen Patienten ist anzufügen, daß diese in keinem direkten $\mathrm{Zu}-$ sammenhang mit der Ausdehnung der Halsdissektion standen. Hervorzuheben ist, daß 6 der 8 Todesfälle in der 1 . Hälfte des Beobachtungszeitraumes seit Anwendung des Behandlungskonzeptes aufgetreten waren. In der 2. Hälfte wird die perioperative Mortalität zusätzlich durch eine größere Patientenzahl auf unter $5 \%$ gesenkt und damit mehr als halbiert. Durch Fortschritte im präoperativen Screening und durch zusätzliche Möglichkeiten zur Verbesserung des Allgemeinzustandes der Patienten (1) wird eine weitere Reduktion bzw. Elimination angestrebt.

\section{Literatur}

(1) Glaser C, Gössweiner S, Millesi W, Watzinger F, Lang S, Dobrowsky W, Ewers R. Kornek GV: R-Hu-Erythropoietin-Substitution verbessert die Effizienz der neoadjuvanten Radio-Chemotherapie bei Patienten mit Mundschieimhaut- und Oropharynxkarzinomen. Acta Chir Austriaca 1998;30 (supp! 141): 12.

\section{Kongreßankündigung / Congress Announcement}

\section{Fortbildungsseminar der}

\section{Österreichischen Gesellschaft für Chirurgie}

Termin und Ort: 11 . und 12. Dezember 1998, Salzburg.

Organisation: $\quad$ Prof. Dr. H. W. Waclawiczek (Fortbil-

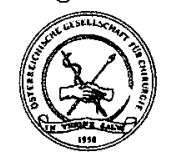
dungsreferent), Landeskrankenanstalten Salzburg, I. Chirurgische Abteilung, Müllner Hauptstraße 48, A-5020 Salzburg, Tel. ++43/622/44 82 DW 31 03, Fax DW 3104. 